Jurnal IImiah AL-Jauhari (JIAJ)

Volume 4 No 1, (Juni 2019): 126-151

p-ISSN: $2541-3430$

Website: http://journal.iaingorontalo.ac.id/index.php/aj

\title{
Pengaruh Kearifan Lokal dan Kecerdasan Spiritual terhadap Perilaku Peserta Didik
}

\author{
Kusno Setiadi \\ (Guru SMA Negeri 1 Kabila) \\ kusnosetiadi17@gmail.com
}

\begin{abstract}
This article aims to reveal the influence of local wisdom and spiritual intelligence on the behavior of students in Kabila 1 Public High School. Assessment is carried out with quantitative approaches and survey methods. The data analysis technique used is the analysis of the product moment correlation coefficient and multiple linear regression. The results of the study indicate that: (1) there is a significant influence between local wisdom on student behavior, and the correlation of determination is $17.9 \%$. (2) there is a strong influence between spiritual intelligence on students' behavior and the correlation of determination is $50.8 \%$. (3) there is a strong influence between local wisdom and spiritual intelligence together on student behavior and the correlation of determination is $50.41 \%$. Furthermore, $49.59 \%$ of students' good behavior is influenced by other factors. This is what causes the Kabila 1 Public High School to implement local wisdom-based education and provide spiritual activities in schools in order to cope with the bad behavior of students.
\end{abstract}

\section{Abstrak}

Artikel ini bertujuan mengungkapkan pengaruh kearifan lokal dan keceradasan spiritual terhadap perilaku peserta didik di SMA Negeri 1 Kabila. Pengkajian dilakukan dengan pendekatan kuantitatif dan metode survei. Teknik analisis data yang digunakan yaitu analisis 
koefisien korelasi product moment dan regresi linier berganda. Hasil kajian menunjukkan bahwa: (1) terdapat pengaruh yang cukup berarti antara kearifan lokal terhadap perilaku peserta didik, dan korelasi determinasinya sebesar $17,9 \%$. (2) terdapat pengaruh yang kuat antara kecerdasan spiritual terhadap perilaku peserta didik dan korelasi determinasinya sebesar 50,8\%. (3) terdapat pengaruh yang kuat antara kearifan lokal dan kecerdasan spiritual secara bersama-sama terhadap perilaku peserta didik dan korelasi determinasinya sebesar 50,41\%. Selanjutnya 49,59\% perilaku baik peserta didik dipengaruhi faktor lain. Hal inilah yang menyebabkan di SMA Negeri 1 Kabila menerapkan pendidikan berbasis kearifan lokal dan pengadaan kegiatan spiritual di sekolah dalam rangka menanggulangi perilaku buruk peserta didik.

Keywords: local wisdom; spiritual, intelligence,

\section{Pendahuluan}

Dunia saat ini memasuki masa yang disebut era globalisasi. Globalisasi membuat banyak hal semakin mudah berkembang. Teknologi yang semakin canggih dan kemudahan seseorang dalam berkomunikasi merupakan ciri dunia memasuki era global. Kemajuan di era globalisasi memberikan dampak negatif yang tidak sedikit bagi masyarakat, khususnya kaum muda-mudi. Remaja dipahami sebagai kalangan yang sangat mudah terkena dampak globalisasi. Salah satu dampak negativ tersebut adalah pergaulan bebas.

Pergaulan bebas merupakan produk era globalisasi. Dampak globalisasi dapat dengan mudah menyerang berbagai aspek kehidupan. Tidak peduli besar kecil, tua muda, pria wanita, semua lapisan masyarakat dapat terkena dampak negative globalisasi. Oleh karena itu, Indonesia yang merupakan bangsa yang memegang adat budaya timur wajib untuk menyelamatkan rakyatnya, terutama para remaja dari arus globalisasi. Pergaulan bebas pada remaja identik dengan istilah kenakalan remaja.

Kenakalan peserta didik mengharuskan bahwa semua pihak berkontribusi menangulangi kasus peserta didik yang melanggar aturan-aturan di sekolah. Keterpaduan dari berbagai pihak dalam memerangi kenakalan peserta didik memang sangat dibutuhkan. Mulai dari tataran individu, kelompok hingga mayarakat. Disamping diperlukan keseriusan dalam penanganan sehingga tidak terkesan setengah hati karena kenakalan remaja khususnya di Indonesia telah menjadi ancaman serius bagi masa depan bangsa. 
Di abad 21 ini, bangsa Indonesia dihadapkan pada kondisi yang serba dilematis. betapa tidak, gambaran kehidupan masyarakat saat ini adalah identik dengan kebebasan, kemewahan, gaya hidup, dan kebudayaan popular turut mengikuti kemajuan kehidupan modern. Disatu sisi, orang dituntut untuk menghadapi dan menyambut era globalisasi agar tidak dianggap ketinggalan zaman dan mengelak dari adanya perubahan yang bisa membawa kemajuan bagi kehidupan manusia. Namun disisi lain, orang perlu memelihara nilai-nilai luhur budaya bangsa dan kecerdasan dalam meng-counter dan kemampuan mem-filter pengaruh globalisasi agar tidak terkontaminasi oleh dampak negative yang dibawa dengan tetap menjunjung tinggi nilainilai moralitas dan budaya sendiri sebagai identitas bangsa Indonesia.

Moral atau budi pekerti dapat ditanamkan kepada peserta didik melalui pengetahuan tentang kebudayaan-kebudayaan Indonesia. Pengetahuan tentang kebudayaan penting bagi peserta didik terutama ketika berada dalam era perubahan yang cepat. ${ }^{1}$ Kebudayaan mencakup semua warisan budaya manusia seperti pengetahuan, keterampilan, nilai-nilai, adat istiadat, kebiasaan, cita-cita, sikap, kepercayaan, dan cara berpikir suatu kelompok. ${ }^{2}$ Kebudayaan membentuk seseorang bertingkah laku kultural. Dengan berbekal tingkah laku yang kultural peserta didik bisa berfungsi atau diterima di kelompok, dan bertingkah laku baik.

Sekolah selaku penyelenggara pendidikan merupakan instrumen untuk mempertahankan dan mewariskan kebudayaan yang baik untuk kehidupan peserta didik. Bertutur kata yang baik, rukun, sopan santun, berpakaian rapi sesuai aturan, taat terhadap aturan atau norma yang berlaku merupakan refleksi dari nilai-nilai budaya yang baik. Kebudayaan yang masih terjaga kelestariannya disebut kearifan lokal.

Kearifan lokal merupakan bahan kajian atau mata pelajaran pada satuan pendidikan yang berisi muatan dan proses pembelajaran tentang potensi dan keunikan lokal yang dimaksudkan untuk membentuk pemahaman peserta didik perhadap keunggulan dan kearifan di daerah tempat tinggalnya. Kearifan lokal dimaksudkan diajarkan dengan tujuan membekali peserta didik dengan sikap, pengetahuan, dan keterampilan yang diperlukan untuk: (a) mengenal dan mencintai lingkungan alam, sosial, budaya, dan spiritual di daerahnya, dan (b) melestarikan dan mengembangkan keunggulan dan kearifan daerah yang berguna bagi diri dan lingkungannya dalam

\footnotetext{
${ }^{1}$ Mohammad Ansyor, Kurikulum Hakikat, Fondasi, Desain, dan Pengembangan, (Jakarta: Kencana Media, 2015), hlm. 143.

${ }^{2}$ Mohammad Ansyor, Kurikulum Hakikat, Fondasi, Desain, dan Pengembangan, hlm. 145.
} 
rangka menunjang pembangunan daerah dan nasional. Dengan mempertahankan kebudayaan daerah maka peserta didik tidak akan mudah terkena dampak negativ globalisasi.

Pendidikan budaya kearifan lokal merupakan upaya eksternal dalam menanggulangi perilaku peserta didik yang menyimpang. Tentunya upaya perbaikan perilaku peserta didik kurang jika hanya pengandalkan aspek dari luar saja. Artinya upanya menanggulangi perilaku peserta didik yang dianggap melanggar aturan sekolah harus didukung dari aspek internalnya yaitu kecerdasan.

Faktor lain yang dianggap bisa meng-counter dampak negative globalisasi adalah kecerdasan. Peserta didik yang memiliki kecerdasan yang tinggi, maka akan mudah memahami dan memecahkan suatu masalah. Kemampuan dalam memahami dan memecahkan masalah merupakan indikator yang membedakan orang yang cerdas dan kurang cerdas. Berkenaan dengan proses belajar peserta didik di sekolah, kecerdasan dapat menentukan kualitas belajar peserta didik. ${ }^{3}$ Peserta didik yang mempunyai tingkat kecerdasan yang tinggi akan lebih berhasil dari pada yang mempunyai kecerdasan rendah. ${ }^{4}$ Maknanya semakin tinggi tingkat kecerdasannya peserta didik, semakin besar peluang meraih prestasi dalam belajar. Sebaliknya, semakin rendah tingkat kecerdasan peserta didik, semakin sulit mencapai kesuksesan belajar.

Kecerdasan yang dianggap bisa dijadikan perangkat kontrol perilaku manusia adalah kecerdasan spiritual. Sebagaimana yang dikemukakan oleh Ary Ginanjar Agustian yang menyatakan bahwa dalam kecerdasan spiritual ada prinsip-prinsip membangun mental, diantaranya prinsip bintang yang di dalamnya dikemukakan bahwa dalam diri setiap manusia memiliki sifat keindahan dan ingin selalu mulia yang merupakan hakikat jiwa yang diberikan oleh Yang Maha Kuasa, yang menjadi dasar keberhasilan dan bila seseorang telah menyadari sifat-sifatnya jika terus dipupuk menghasilkan kekuatan serta motivasi yang maha dasyat. ${ }^{5}$ Dalam kecerdasan spiritual juga memuat prinsip pembelajaran, yang mengarahkan manusia untuk senantiasa menggali dan mengembangkan ilmu pengetahuan serta memiliki pedoman kuat dalam belajar, yaitu berpegang kepada

\footnotetext{
${ }^{3}$ Baharuddin dan Esa Nur Wahyuni, Teori Belajar dan Pembelajaran, (Yogyakarta: Ar-Ruzz Media, 2010), Cet., ke-5, hlm. 21.

${ }^{4}$ Slameto, Belajar dan Faktor-faktor yang Mempengaruhinya, (Jakarta: PT Rineka Cipta, 2004), Cet., ke-4, hlm. 57.

${ }^{5}$ Ary Ginanjar Agustian, Rahasia Sukses Membangun Kecerdasan Emosi Dan Spiritual ESQ Emotianal Spiritual Quotient The ESQ Way 1651 Ihsan, 6 Rukun Iman Dan 5 Rukun Islam, (Jakarta: Arga, 2001), hlm. 134-135.
} 
Alquran. ${ }^{6}$ Kecerdasan spiritual menjadikan seseorang yang benarbenar utuh secara intelektual, emosional dan spiritual.

Peserta didik di Bone Bolango bahkan di Indonesia memiliki tingkat kecerdasan spiritual yang tinggi maka dampak negative pergaulan bebas bukan hal yang sulit untuk ditanggulangi. Hal ini setidaknya dengan alasan: (1) kecerdasan spiritual akan menjadikan peserta didik dapat mempergunakan secara harmonis dua kecerdasan lainnya yang dimilliki secara efektif; (2) kecerdasan spiritual yang dimiliki peserta didik akan membawanya berpikir optimis, tidak pesimis, cemas, takut terhadap permasalahan yang dihadapi; (3) dalam konsep Islam, manusia harus melakukan apa yang diperintahkan Allah dan menjauhi segala larangan-Nya.

Pada akhirnya banyak ahli psikologi dan pendidikan, kecerdasan spiritual (SQ) direferensikan sebagai jalan keluar untuk mengatasi problem peserta didik. Sebagaimana dapat disaksikan, saat ini kita sering mendengar terjadi masalah yang menyangkut bidang pendidikan. Berbagai masalah yang terjadi biasanya tentang perilaku peserta didik.

Banyak ditemukan kasus perilaku peserta didik yang terjadi di sekolah. Kasus-kasus tersebut antara lain memaki, sering datang terlambat, membolos, ketidakhadiran tanpa izin, merokok, pacaran, perkelahian dan bermain handphone saat jam pelajaran berlangsung.

Penulis menemukan kasus - kasus pelanggaran aturan sekolah yang dilakukan peserta didik dari catatan jurnal guru bimbingan dan konseling di SMA Negeri 1 Kabila semester ganjil tahun pelajaran 2016-2017 diantaranya: Kasus peserta didik yang datang terlambat ke sekolah, membolos, alpa lebih dari 3 hari, pacaran yang menimbulkan ketidaknyamanan salah satu pelakunya, pelanggaran tata tertib berpakaian, merokok, lompat pagar sekolah dan melanggar aturan di sekolah dalam bentuk makian terhadap seorang guru. ${ }^{7}$

Mencermati fenomena yang terjadi pada peserta didik saat ini dengan kompleksnya permasalahan peserta didik, setidaknya bukan sekedar masalah apakah para peserta didik ini tahu baik tidaknya tindakan yang dilakukan? Tetapi adanya sesuatu yang kurang bahkan hilang, yaitu perangkat dalam diri peserta didik untuk dapat mengontrol, mengendalikan dan memotivasi diri terutama kesadaran memegang kuat nilai-nilai agama dalam kehidupan sehari-hari.

\footnotetext{
${ }^{6}$ Ary Ginanjar Agustian, Rahasia Sukses Membangun Kecerdasan Emosi Dan Spiritual ESQ Emotianal Spiritual Quotient The ESQ Way 1651 Ihsan, 6 Rukun Iman Dan 5 Rukun Islam., hlm. 201.

${ }^{7}$ Jurnal Mutia Botutihe, guru bimbingan dan konseling SMA Negeri 1 Kabila.
} 
Dari beberapa lembaga pendidikan di Bone Bolango, penulis menemukan terdapat salah satu lembaga pendidikan yang aktif mengupayakan penanggulangan kenakalan peserta didik yaitu SMA Negeri 1 Kabila melalui pembelajaran yang mengandung nilai-nilai kearifan lokal dan spiritual.

Penanaman nilai-nilai budaya kearifan lokal bisa dilakukan dengan cara: (1) memasukan budaya kedalam materi pelajaran. Seni tari tradisional Gorontalo bagian dari pelajaran seni budaya untuk peserta didik SMA/SMK/MA. Tarian tradisional Gorontalo bukan saja berisi materi pembelajaran yang dirancang hanya untuk mengasah kompetensi keteramplan dan pengetahuan saja. Tetapi lebih dari itu, peserta didik selain dibekali pengetahuan tentang gerak tari dalam konteks seni, juga membangkitkan motivasi historis pewarisan budaya dan nilai-nilai estetik sejarah para leluhur sebagai kekayaan budaya Nasional yang berasal dari Gorontalo.

Adapun kegiatan spiritual yang dilakukan di SMA Negeri 1 Kabila berupa mengikuti "walimah" membuat "tolangga" pada perayaan Maulid Nabi Muhammad Saw., kegiatan rohani Islam (Rohis) setiap hari kamis selesai jam pelajaran normal, membaca QS. Yasin pada hari Jum'at dan SENADA (Seni Nada dan Dakwah) yang dilakukan setiap hari Sabtu pada jam pelajaran ke 1. Rutinitas kegiatan spiritual merupakan upaya pengembangan dalam meningkatkan kecerdasan spiritual peserta didik di sekolah. Upaya tersebut pada dasarnya untuk membekali siswa dengan pondasi keagamaan yang kuat dan selalu berserah diri kepada Allah setelah berusaha menyelesaikan tugas atau permasalahannya. Di samping itu juga untuk membekali peserta didik untuk senantiasa tegar menghadapi tekanan psikis dan meng-erem prilaku buruk yang dapat menghambat pencapaian prestasi belajarnya.

\section{Kearifan Lokal}

Kebudayaan kaitannya erat dengan masyarakat. Segala sesuatu yang terdapat dalam masyarakat ditentukan oleh kebudayaan yang terdapat di masyarakat itu sendiri. Budaya merupakan cara hidup yang berkembang dan dimiliki bersama oleh sebuah kelompok orang dan diwariskan dari generasi ke generasi. Sebagaimana yang dikemukakan oleh Edward B. Tylor yang dikutip oleh Eko Digdoyo mengemukakan bahwa budaya merupakan keseluruhan kompleks yang meliputi pengetahuan, kepercayaan seni, moral, adat istiadat, serta serta kesanggupan dan kebiasaan lainnya yang dipelajari oleh manusia 
sebagai anggota masyarakat. ${ }^{8}$ Kebudayaan mencakup ciptaan, norma kehidupan, kepercayaan, tradisi, loyalitas, tingkah laku, moral, kontrol diri, dan harapan, serta nilai-nilai, bahasa, cita-cita, aspirasi, dan pandangan hidup. ${ }^{9}$

Singkat kata Kebudayaan merupakan hasil karya manusia yang bersumber dari keyakinan dan keterampilan yang tidak dibawa secara genetik, melainkan sesuatu yang diperoleh dan dipelajari melalui interaksi sosial dan peniruan. Ini berarti bahwa masyarakat terdiri atas sekelompok manusia yang lebih banyak berinteraksi satu sama lain dan bekerja sama untuk mencapai tujuan bersama yaitu mencapai kehidupan individu dan bersama yang tentram dan damai. Kebudayaan yang masih dilestarikan oleh anggotanya sampai saat ini maka dapat dipahami sebagai kearifan lokal.

Kearifan lokal sebagaimana yang diinformasikan Putut Setiyadi bahwa kearifan lokal merupakan adat dan kebiasan yang telah mentradisi dilakukan oleh sekelompok masyarakat secara turun temurun yang hingga saat ini masih dipertahankan keberadaannya oleh masyarakat hukum adat tertentu di daerah tertentu. ${ }^{10}$ Pendapat yang serupa dikemukakan oleh Zuhdan K. Prasetyo menjelaskan bahwa local wisdom (kearifan lokal) dapat dipahami sebagai gagasangagasan setempat (lokal) yang bersifat bijaksana, penuh kearifan, bernilai baik, yang tertanam dan diikuti oleh anggota masyarakatnya. ${ }^{11}$ Kearifan lokal tumbuh dan terus dilestarikan di masyarakat dikarenakan hal tersebut memiliki penilaian positif oleh masyarakat setempat.

Adapun Nuraini Asriati berpandangan bahwa kearifan lokal merupakan suatu gagasan konseptual yang hidup dalam masyarakat, tumbuh dan berkembang secara terus-menerus dalam kesadaran masyarakat dari yang sifatnya berkaitan dengan kehidupan yang sakral sampai dengan yang profan (bagian keseharian dari hidup dan sifatnya biasa-biasa saja). ${ }^{12}$ Hal senada disampaikan oleh Haidlor Ali Ahmad yang mengemukakan bahwa kearifan lokal adalah suatu sintesa

${ }^{8}$ Eko Digdoyo, Ilmu Sosial dan Budaya Dasar, (Bogor: Ghalia Indonesia, 2015), hlm. 53.

${ }^{9}$ Mohammad Ansyor, Kurikulum Hakikat, Fondasi, Desain, dan Pengembangan, (Jakarta: Kencan Media, 2015), hlm. 149.

${ }^{10}$ Putut Setiyadi, Pemahaman Kembali Local Wisdom Etnik Jawa dalam Tembang Macapat dan Pemanfaatannya sebagai Media Pendidikan Budi Pekerti Bangsa. (Yogyakarta: Magistra, 2012), hlm. 75

${ }^{11}$ Zuhdan K. Prasetyo,Pembelajaran Sains Berbasis Kearifan Lokal. Prosidind, Seminar Nasional Fisika dan Pendidikan Fisika. Surakarta. (FKIP UNS, 2013), hlm. 3.

${ }^{12}$ Nuraini Asriati, Mengembangkan Karakter Peserta Didik Berbasis Kearifan Lokal Melalui Pembelajaran di Sekolah. (Jurnal Pendidikan Sosiologi dan Humaniora), 2 (III), 2012) hlm. 111. 
budaya yang diciptakan oleh aktor-aktor lokal melalui proses yang berulangulang, melalui internalisasi dan interpretasi ajaran agama dan budaya yang disosialisasikan dalam bentuk norma-norma dan dijadikan pedoman dalam kehidupan sehari-hari bagi masyarakat. ${ }^{13}$ Kearifan lokal senantiasa terjaga kelestariannya dari generasi ke generasi. Hal ini terjadi karena masyarakat dalam menjalakan kehidupannya di masyarakat tidak jauh yaitu melanjutkan pola adat kebiasaan hidup di lingkungan tempat tinggalnya.

Kearifan lokal merupakan pengetahuan dasar yang diperoleh dari keseimbangan hidup dengan alam, hal ini terkait dengan kebudayaan masyarakat yang terakumulasi secara terus-menerus. Kearifan lokal mengacu pada pengetahuan yang berasal dari pengalaman masyarakat dan merupakan akumulasi dari pengetahuan lokal.

Nuraini Asriati mengatakan bahwa bentuk kearifan lokal dalam masyarakat dapat berupa budaya (nilai, norma, etika, kepercayaan, adat istiadat, hukum adat, dan aturan-aturan khusus). ${ }^{14}$ Nilai-nilai luhur terkait kearifan lokal ialah:

a. Cinta kepada Tuhan, alam semester beserta isinya.

b. Tanggungjawab, disiplin, dan mandiri.

c. Jujur.

d. Hormat dan santun.

e. Kasih sayang dan peduli.

f. Percaya diri, kreatif, kerja keras, dan pantang menyerah.

g. Keadilan dan kepemimpinan.

h. Baik dan rendah hati.

i. Toleransi, cinta damai, dan persatuan.

Pendidikan Berbasis Kearifan Lokal merupakan usaha sadar yang terencana melalui penggalian dan pemanfaatan potensi daerah setempat secara arif dalam upaya mewujudkan suasana belajar dan proses pembelajaran, agar peserta didik aktif mengembangkan potensi dirinya untuk memiliki keahlian, pengetahuan dan sikap dalam upaya ikut serta membangun bangsa dan negara.

Haidlor Ali Ahmad mengemukakan kearifan lokal merupakan tata aturan tak tertulis yang menjadi acuan masyarakat yang meliputi seluruh aspek kehidupan, berupa: ${ }^{15}$

\footnotetext{
${ }^{13}$ Haidlor Ali Ahmad, Kearifan Lokal sebagai Landasan Pembangunan Bangsa,(Harmoni Jurnal Multikultural \& Multireligius. 34 (IX), 2010), hlm. 5.

${ }_{14}$ Nuraini Asriati, Mengembangkan Karakter Peserta Didik Berbasis Kearifan Lokal Melalui Pembelajaran di Sekolah.(Jurnal Pendidikan Sosiologi dan Humaniora, 2010), hlm.111.

${ }^{15}$ Haidlor Ali Ahmad. Kearifan Lokal sebagai Landasan Pembangunan Bangsa, (Harmoni Jurnal Multikultural \& Multireligius. 34 (IX). 2010), hlm. 34.
} 
- Tata aturan yang menyangkut hubungan antar sesama manusia, misalnya dalam interaksi sosial baik antar individu maupun kelompok, yang berkaitan dengan hirarkhi dalam kepemerintahan dan adat, aturan perkawinan antar klan, tata karma dalam kehidupan sehari-hari.

- Tata aturan menyangkut hubungan manusia dengan alam, binatang, tumbuh-tumbuhan yang lebih bertujuan pada upaya konservasi alam.

- Tata aturan yang menyangkut hubungan manusia dengan yang gaib, misalnya Tuhan dan roh-roh gaib. Kearifan lokal dapat berupa adat istiadat, institusi, kata-kata bijak, pepatah (Jawa: parian, paribasan, bebasan dan saloka).

Dalam masyarakat, kearifan-kearifan lokal dapat ditemui dalam nyayian, pepatah, sasanti, petuah, semboyan, dan kitab-kitab kuno yang melekat dalam perilaku sehari-hari. Sama halnya dengan pendapat Nurma Ali Ridwan ${ }^{16}$ yang mengatakan bahwa kearifan lokal ini akan mewujud menjadi budaya tradisi, kearifan lokal akan tercermin dalam nilai-nilai yang berlaku dalam kelompok masyarakat tertentu.

\section{Nilai Tradisi Tolangga di Gorontalo}

Salah satu daerah di Indonesia yang kaya akan budaya adalah Gorontalo. Budaya Gorontalo sangat dipengaruhi oleh ajaran Islam dan banyak unsur ajaran agama yang menjadi budaya masyarakat Gorontalo. Salah satu upacara adat Gorontalo yang bernuansa Islami adalah perayaan mauled Nabi Muhammad SAW. Masyarakat Gorontalo menyebutnya dengan walima. Setiap ada kegiatan walima, masyarakat gorontalo membuat tolangga.

Tolangga adalah wadah atau tempat diletakkannya makanan yang akan di bawa ke masjid. Ada dua unsur utama pembentuk tolangga, yaitu lilingo dan toyopo. Lilingo adalah wadah seperti loyang yang berbentuk bundar, dan ternuat dari daun kelapa muda atau janur kuning. Makna yang terkandung dari lilingo sebagai tempat makanan adalah diharapkan umat manusia terutama umat muslim dapat saling bantu-membantu menjaga persatuan dan kesatuan sebagai umat muslim yang diajarkan Nabi Muhammad SAW. Adapun janur kuning adalah warna adat yang indah maknanya diharapkan semua

\footnotetext{
${ }^{16}$ Nurma Ali Ridwan, Landasan Keilmuan Kearifan Lokal. Jurnal Studi Islam dan Budaya. 1(V). 2007), hlm. 7.
} 
umat manusia dapat bertutur kata yang indah, berperilaku yang santun, dan memiliki jiwa yang bersih. ${ }^{17}$

Selain lilingo ada toyopo. Toyopo adalah lilingo yang telah diisi beberapa macam kue dan makanan, kemudian diatur sedemikian rupa hingga terbentuk menyatu di atas seperti piramid. Makna dari toyopo adalah membentuk satu kesatuan, terangkul dan tidak terpisahkan.

Kue-kue yang terdapat pada tolangga biasanya terdiri dari berbagai jenis kue khas masyarakat Gorontalo. Berikut nama-nama kue yang terdapat di tolangga beserta maknanya: ${ }^{18}$

a. Tutulu : manusia diciptakan memiliki hati yang sama dan diharapkan selalu dijaga.

b. Kolombengi : pengharapan agar manusia menjadi umat manusia yang berjiwa besar dan selalu berusaha menjadi orang yang dicintai Allah SWT dan Rasul-Nya.

c. Apang coe : pengharapan manusia agar hatinya selalu diberi kedamaian dan selalu diberkati oleh Allah SWT dan agar hatinya selalu teguh, berani mengakui ke-Esaan Allah SWT. dan adanya Nabi Muhammad sebagai Rasulullah yang dapat menolong umat manusia yang selalu beriman dan mengakui ajaran-ajarannya.

d. Sukade : menjadi manusia yang hidup dengan penuh kesederhanaan dan kesabaran serta ikhlas akan dapat menjalani hidup bahagia di dunia dan akhirat kelak, asalkan selalu menjaga keimanannya.

e. Panada dan lalampa: pengharapan manusia berperilaku baik, artinya bukan hanya di luar yang berperilaku baik tetapi di dalam dirinya juga mencerminkan manusia yang beriman dan berilmu.

f. Wapili : pengharapan manusia memiliki kasih sayang yang dijaga antar sesame manusia, menunjukan sikap manusia yang memiliki hati yang lapang dan penuh kesabaran, semoga Allah SWT tetap menjaga dan memperteguhkan hati antar sesam manusia dengan ajaran Islam.

Makna lain yang terdapat dari pembuatan tolangga adalah masyarakat yang memberikan tolangga tidak mengharapkan imbalan, namun semua yang diberikan dan dihidangkan dianggap sebagai doa

\footnotetext{
${ }^{17}$ Anastasia Hastuti Abdullah, dkk, Menjaga Nilai Tradisi Tolangga di Gorontalo Antologi Esai Remaja Gorontalo 2015, (Gorontalo: Kantor Bahasa Provinsi Gorontalo, 2015), hlm. 4.

${ }^{18}$ Anastasia Hastuti Abdullah, dkk, Menjaga Nilai Tradisi Tolangga di Gorontalo Antologi Esai Remaja Gorontalo 2015, hlm. 5-7.
} 
untuk Rasulullah, sahabat, dan keselamatan bagi seluruh umat manusia.

\section{Konsep Pendidikan Berbasis Kearifan Lokal}

Kearifan Lokal dalam hal ini juga dapat disebut dengan keunggulan lokal, local genius atau local wisdom, seperti yang dikatakan oleh Kemendikbud bahwa Istilah local wisdom, local genius, kearifan Lokal, yang kemudian disebut keunggulan lokal. ${ }^{19}$ Kearifan lokal dapat dimasukkan ke dalam pendidikan sebagai salah satu usaha untuk melestarikan budaya lokal yang terdapat pada suatu daerah.

Pendidikan Berbasis Kearifan Lokal menurut Zuhdan K. Prasetyo merupakan usaha sadar yang terencana melalui penggalian dan pemanfaatan potensi daerah setempat secara arif dalam upaya mewujudkan suasana belajar dan proses pembelajaran, agar peserta didik aktif mengembangkan potensi dirinya untuk memiliki keahlian, pengetahuan dan sikap dalam upaya ikut serta membangun bangsa dan negara. ${ }^{20}$

Sekolah berbasis kearifan lokal memberikan fasilitas kepada siswa untuk mempelajari budaya lokal yang ada di daerah tinggal. Kegiatan tersebut dapat berupa ekstrakurikuler atau kegiatan sekolah setiap tahunnya. Oleh karena itu, Made Pidarta mengatakan bahwa pendidikan membuat orang berbudaya ${ }^{21}$. Tidak hanya berupa kegiatan, pada proses pembelajaran bukan hanya menyampaikan budaya kepada siswa, melainkan lebih kepada menggunakan budaya tersebut agar siswa menemukan makna, kreativitas, dan memperoleh pemahaman yang lebih mendalam tentang materi yang sedang dipelajari. Masing-masing guru memiliki kreativitas untuk merancang dan melaksanakan pembelajaran berbasis kearifan lokal. Selain itu, guru juga harus berani mengambil resiko untuk menciptakan proses pembelajaran yang kreatif.

Sekolah berbasis kearifan lokal seirama dengan upaya pemerintah dalam melestarikan budaya yang ada di Indonesia. Saat ini generasi muda penerus bangsa mulai meninggalkan budayanya sendiri dan beralih kepada budaya barat. Hal yang mencoreng nama Indonesia adalah dengan adanya peristiwa beberapa tahun belakangan. Salah satu penyebab kejadian tersebut adalah generasi muda tidak mau mempelajari budaya sendiri. Herimanto mengatakan bahwa dalam

\footnotetext{
${ }^{19}$ Zuhdan K. Prasetyo, Pembelajaran Sains Berbasis Kearifan Lokal, (Surakarta: Seminar Nasional Fisika dan Pendidikan Fisika. FKIP UNS, 2013), hlm. 3

${ }^{20}$ Zuhdan K. Prasetyo, Pembelajaran Sains Berbasis Kearifan Lokal, hlm. 3

${ }^{21}$ Made Pidarta, Landasan Kependidikan. (Jakarta: PT Rineka Cipta, 2007), hlm.3
} 
suatu kasus, ditemukan generasi muda menolak budaya yang hendak oleh generasi pendahulunya. ${ }^{22}$

Dari teori-teori di atas, setelah disintesis maka dapat dipahami bahwa kearifan lokal adalah nilai-nilai luhur yang dimiliki seseorang karena taat dan patuh terhadap tata aturan yang menyangkut hubungan antar sesama manusia, tata aturan yang menyangkut hubungan manusia dengan alam, dan tata aturan yang menyangkut hubungan manusia dengan hal-hal gaib sebagai aspek kebudayaan yang terdapat di daerahnya.

Kecerdasan merupakan kata yang cukup sering terdengar untuk menggambarkan kemampuan seseorang. Namun pengertian kata ini berbeda-beda antara tokoh satu dengan yang lainnya. Pengertian yang lebih sederhana dikemukakan oleh Piaget sebagaimana dikutip oleh Aliah B. Purwakania Hasan, mendefinisikan kecerdasan atau inteligensi sebagai pikiran atau tindakan adaptif. ${ }^{23}$ Pendapat yang berbeda memberikan penekanan pada kemampuan memecahkan masalah-masalah abstrak. J.P Chaplin merumuskan definisi kecerdasan yaitu, (1) kemampuan menghadapi dan menyesuaikan diri terhadap situasi baru secara cepat dan efektif, (2) kemampuan menggunakan konsep abstrak secara efektif, yang meliputi empat unsur, seperti memahami, berpendapat, mengontrol dan mengritik, dan (3) kemampuan memahami pertalian-pertalian dan belajar dengan cepat sekali. ${ }^{24}$

Dengan kata lain, kecerdasan spiritual menjadikan anak untuk menyadari keberadaan Tuhan, di manapun dan kapan pun. Kemudian kesadaran itu berpengaruh terhadap segala perbuatannnya sehingga hampir seluruh aktivitas anak dikendalikan oleh kesadaran transenden dalam dirinya.

Ramayulis berpendapat dalam hal peningkatan kecerdasan spiritual yaitu dengan pendekatan agama. Dalam bukunya yang berjudul Ilmu Pendidikan Islam, Ramayulis mengemukakan keceradasan spiritual dapat dikembangkan dengan berbagai cara, yaitu: ${ }^{25}$

\footnotetext{
${ }^{22}$ Herimanto dan Winarno, Ilmu Sosial dan Budaya Dasar. (Jakarta: PT Bumi Aksara, 2010), hlm.34

${ }^{23}$ Aliah B. Purwakania Hasan, Psikologi Perkembangan Islam Menyingkap Rentang Kehidupan Manusia dari Prakelahiran hingga Pascakematian, (Jakarta: Raja Grafindo Persada, 2006), hlm. 151.

${ }^{24}$ J.P. Chaplin, Kamus Lengkap Psikologi, terj. Kartono Kartini, Judul asli, "Dictionary of Psychology", (Jakarta : Rajawali Pers, 1999), hlm. 253.

${ }^{25}$ Ramayulis, Ilmu pendidikan Islam, (Jakarta: Kalam Mulia, 2010), Cet., ke-9,hlm. 108.
} 
a. Melalui Iman

Iman adalah sumber ketenangan batin dan keselamatan kehidupan. Orang yang beriman akan selalu berlindung kepada Allah. Ia akan patuh terhadap perintah Allah dan menjauhi larangan-Nya. Akibat dari iman, seseorang menerima semua kehendak Allah untuknya.

b. Melalui Ibadah

Ibadah dapat menjadikan seseorang yang melakukan merasa tenang jiwanya. Semakin banyak beribadah semakin tenang pula hidupnya. Kehidupan yang terasa tenang karena jiwa tenang. Jiwa yang tenang merupakan salah satu indikator kecerdasan spiritual.

Dari uraian di atas, menunjukkan bahwa iman dapat meringankan beban psikis seseorang dari pengaruh kegelisahan, kekawatiran, ketakutan serta menimbulkan ketenangan dan kedamaian dalam jiwanya. Adapaun ibadah merupakan bagian dari ritual keagamaan yang dapat memberikan ketenangan batin dan memupuk keseimbangan hidup seseorang.

\section{Metodologi Penelitian}

Jenis penelitian ini adalah penelitian lapangan (field research) karena pengambilan datanya dari lapangan yaitu SMA Negeri 1 Kabila. Adapun metode yang digunakan dalam penelitian ini adalah metode survei dengan menggunakan teknik korelasional.

Sebagai populasi pada penelitian ini adalah seluruh peserta didik SMA Negeri 1 Kabila Tahun Ajaran 2016-2017 yang berjumlah 958 orang. ${ }^{26}$ Untuk mengetahui jumlah sampel yang diambil dalam penelitian ini, teknik pengambilan sampling menggunakan teknik proportionate stratified random sampling adalah pengambilan sampel dari anggota populasi secara acak dan berstrata secara proporsional. ${ }^{27}$ Ukuran sampel pada subkelas diambil dengan jumlah sama atau berimbang. Adapun teknik yang dipakai dalam menentukan ukuran sampel dengan menggunakan rumus yang dikemukakan Surakmad Winarno.

Pada penelitian ini, peneliti dalam menganalisa data menggunakan teknik analisis korelasional untuk mengetahui hubungan variabel bebas dengan variabel terikat. Adapun langkahlangkah dalam menganalisis data tersebut, yaitu:

a. Uji Normalitas dan Linieritas

26 Berdasarkan data DAPODIK Peserta didik SMA N 1 Kabila pada semester ganjil bulan Desember Tahun Pelajaran 2016/2017.

${ }^{27}$ Riduwan, Dasar-dasar Statistika, (Bandung: Alfabeta, 2010), Cet., ke-8, hlm. 13 .

Jurnal IImiah AL-Jauhari Volume 4 No 1, (Juni 2019): 126-151 | 138 
Dalam penelitian ini, uji normalitas dilakukan dengan menggunakan uji lilifors sedangkan uji linieritas dilakukan dengan (Analysis of Varian) ANAVA untuk regresi ganda.

b. Regresi

Regresi merupakan peramalan, penaksiran, dan pendugaan. Garis regresi dengan variabel bebas dapat dinyatakan dengan rumus persamaan regresi linier dua variabel.

\section{Pembahasan}

Berdasarkan hasil pengujian yang diuraikan terlebih dahulu terbukti bahwa kearifan lokal dan kecerdasan spiritual berpengaruh secara signifikan terhadap kualitas perilaku peserta didik. Uraian selengkapnya adalah sebagai berikut:

1. Kearifan lokal berpengaruh secara signifikan terhadap perilaku peserta didik

Kearifan lokal adalah pandangan hidup dan ilmu pengetahuan serta berbagai strategi kehidupan yang berwujud aktivitas yang dilakukan oleh masyarakat lokal dalam menjawab berbagai masalah dalam pemenuhan kebutuhan mereka. Dwi Adi Saputra dalam artikelnya berjudul "Menjaga Nilai Kearifan Lokal di Sekolah" berpendapat kearifan lokal dapat dilihat sebagai perilaku positif manusia dalam kehidupnanya dengan alam semesta dan lingkungannya. Artinya nilai-nilai kearifan lokal akan tercermin pada perilaku masyarakat yang melestarikan budaya yang menjadi kearifan lokal di daerah tersebut. Kerarifan lokal itu sendiri dapat bersumber dari nilai agama, adat istiadat, tradisi dan budaya dimana manusia itu hidup.

Menurut Rahyono, kearifan lokal merupakan kecerdasan manusia yang dimiliki oleh kelompok etnis tertentu yang diperoleh melalui pengalaman masyarakat. Artinya, kearifan lokal adalah hasil dari masyarakat tertentu melalui pengalaman mereka dan belum tentu dialami oleh masyarakat yang lain. Nilai-nilai tersebut akan melekat sangat kuat pada masyarakat tertentu dan nilai itu sudah melalui perjalanan waktu yang panjang, sepanjang keberadaan masyarakat tersebut.

Kearifan lokal menjadi suatu kebudayaan unggul dalam masyarakat, sehingga dalam banyak hal yang dikatakan sebagai kearifan lokal terkandung nilai-nilai atau muatan moral. Ada contohcontoh kerifan lokal yang dapat ditemui di masyarakat. Dalam masyarakat di Indonesia dapat ditemui dalam nyanyian, petuah, semboyan dan masih banyak lainnya.

Gorontalo sebagai salah satu daerah yang kental akan nilainilai luhur, tentunya juga merupakan daerah yang banyak memiliki 
nilai-nilai kearifan lokal. Kearifan lokal Gorontalo terwujud dalam semboyan Lamahu. Lamahu sendiri terdiri atas mo huyula yang artinya bersatu, heluma yang artinya gotong royong dan hulondalo yaitu Gorontalo. Sehingga secara kata, Lamahu diartikan sebagai bersatu dan berkerja sama membangun Gorontalo.

Lamahu merupakan semboyan yang sesuai dengan perintah yang terdapat di dalam al-qur'an yaitu QS. Al-Bayyinah ayat 7:

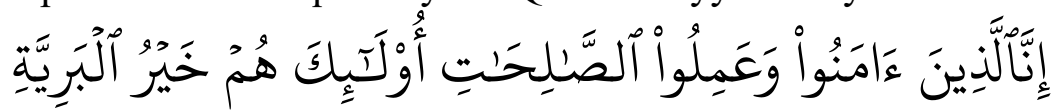

Terjemahnya: "Sesungguhnya orang-orang yang beriman dan mengerjakan amal saleh, mereka itu adalah sebaik-baik makhluk (QS. Al-Bayyinah: 7)”.

Ayat di atas mengisyaratkan bahwa manusia yang baik sebagai hamba Allah tentunya Ia mengerjakan kebaikan-kebaikan secara individu maupun kelompok. Pada kegiatan walimah memiliki unsur bersatu dan berkerja sama. Hal tersebut dapat dipahami dari adanya susunan panitia kegiatan, berzikir bersama-sama, para warga bersamasama membuat tolangga, menyiapkan kue-kue dan makanan lainnya, merangkai walimah, dan selanjutnya dibagikan kepada jamaah zikir, pemimpin do'a, dan warga yang hadir di tempat acara tersebut.

Namun dalam praktek kehidupan nyatanya semangat mo huyula sebagai kearifan lokal ini seakan hilang substansinya. Generasi muda atau peserta didik di sekolah senantiasa menjadi tumpuan harapan perkembangan budaya daerahnya. menjadi perpanjangan tangan pemerintah dalam mengembangkan dan melestarikan kearifan lokal di Gorontalo. Peran dan semangat para generasi muda diyakini menjadi kunci keberhasilan mempertahankan jati diri dan identitas daerahnya yang semakin tergerus oleh perkembangan zaman.

Dewasa ini generasi muda dalam hal ini adalah kau pelajar telah berada pada posisi yang kritis. Banyak peserta didik yang tidak lagi mementingkan rasa kebersamaan, yang seperti ini hanya mementingkan ego masing-masing. Tidak sedikit para peserta didik yang berperilaku tidak sesuai dengan nilai kearifan lokal yang diajarkan oleh daerahnhya. Bahkan ironinya mereka seakan tidak tahuapa saja kearifan lokal Gorontalo yang ada dan bagaimana nilainilai luhur di dalamnya.

Sifat malas juga telah menggerogoti jiwa para peserta didik saat ini, Banyak peserta didik yang terlibat kasus penyipangan social, narkoba, dan bahkan lebih mengadopsi budaya barat. Rasa saling menghormati juga tidak luput dari makin mengikisnya nilai moral dalam diri generasi muda dalam hal ini peserta didik. 
Masalah ini dianggap sebagai bukti nyata hilangnya semangat mempelajari kearifan lokal dalam diri generasi muda. Sehingga perlu dipelajari kembali nilai-nilai kearifan lokal kepada peserta didik di sekolah.

Menurut Haidlor Ali Ahmad mengemukakan kearifan lokal merupakan tata aturan tak tertulis yang menjadi acuan masyarakat yang meliputi seluruh aspek kehidupan, berupa:

- Tata aturan yang menyangkut hubungan antar sesama manusia, misalnya dalam interaksi sosial baik antar individu maupun kelompok, yang berkaitan dengan hirarkhi dalam kepemerintahan dan adat, aturan perkawinan antar klan, tata karma dalam kehidupan sehari-hari.

- Tata aturan menyangkut hubungan manusia dengan alam, binatang, tumbuh-tumbuhan yang lebih bertujuan pada upaya konservasi alam.

- Tata aturan yang menyangkut hubungan manusia dengan yang gaib, misalnya Tuhan dan roh-roh gaib.

Berdasarkan formulasi tata aturan yang berkaitan dengan kearifan lokal di atas, Dimensi/aspek tersebut sebagai pedoman tolak ukur untuk mengevaluasi nilai sikap peserta didik dalam mengaplikasikan nilai -nilai yang terkandung dalam kearifan lokal.

Kearifan lokal dapat dimasukkan ke dalam pendidikan sebagai salah satu usaha untuk melestarikan budaya lokal yang terdapat pada suatu daerah.

Pendidikan Berbasis Kearifan Lokal menurut Zuhdan K. Prasetyo merupakan usaha sadar yang terencana melalui penggalian dan pemanfaatan potensi daerah setempat secara arif dalam upaya mewujudkan suasana belajar dan proses pembelajaran, agar peserta didik aktif mengembangkan potensi dirinya untuk memiliki keahlian, pengetahuan dan sikap dalam upaya ikut serta membangun bangsa dan negara.

Sekolah berbasis kearifan lokal memberikan fasilitas kepada siswa untuk mempelajari budaya lokal yang ada di daerah tinggal. Kegiatan tersebut dapat berupa ekstrakurikuler atau kegiatan sekolah setiap tahunnya. Oleh karena itu, Made Pidarta mengatakan bahwa pendidikan membuat orang berbudaya Tidak hanya berupa kegiatan, pada proses pembelajaran bukan hanya menyampaikan budaya kepada peserta didik, melainkan lebih kepada menggunakan budaya tersebut agar peserta didik menemukan makna, kreativitas, dan memperoleh pemahaman yang lebih mendalam tentang materi yang sedang dipelajari. Masing-masing guru memiliki kreativitas untuk merancang dan melaksanakan pembelajaran berbasis kearifan lokal. Selain itu, 
guru juga harus berani mengambil resiko untuk menciptakan proses pembelajaran yang kreatif.

Efek dari mempelajari kearifan lokal adalah peserta didik diharapkan mampu mentaati tata aturan-aturan baik di lingkungan masyarakat, sekolah maupun keluarga. Nilai-nilai yang terkandung dari kearifan lokal adalah nilai budaya disiplin, nilai saling menghormati, dan nilai kerjasama.

Ide peserta didik mengikuti acara walimah membuat tolangga, mempelajari tarian tidi lo polopalo ini muncul karena saat ini lagi gencar-gencarnya pembentukkan generasi yang siap berinteraksi dengan lingkungan masyarakat. Apalagi kurikulum yang diterapkan di sekolah menerapkan kurikulum 2013, yang mana membutuhkan penilaian terhadap aspek sikap peserta didik.

Program penanaman nilai-nilai kearifan lokal yang dilakukan di SMA Negeri 1 Kabila dikemas dalam acara senada yaitu dijadwalkan setiap jam pembelajaran pertama pada hari Jum'at.

Peran peserta didik dalam kegiatan tersebut dapat memberikan penilaian lebih jelas terhadap peserta didik. Dengan adanya program senada ini peserta didik akal lebih mengenal bagaimana nilai-nilai kearifan lokal yang ada dalam kehidupan masyarakat Gorontalo. Pembelajaran ini juga membantu guru untuk melihat apakah peserta didik taat terhadap aturan-aturan dalam masyarakat lebih khusus di sekolah. Tidak hanya itu juga ide kreatif ini dapat mengajarkan peserta didik untuk saling menghormati sesama, juga gurunya. Mengenalkan, menjaga dan melestarikan budaya yang menjadi kearifan lokal adalah tugas serta tanggung jawab kita semua. lingkungan sekolah cocok untuk mengawali penanaman nilai-nilai kearifan lokal pada peserta didik.

Berdasarkan hasil pengujian korelasi dengan menggunakan korelasi product moment, diperoleh harga korelasi $\left(\mathrm{r}_{\mathrm{yx} 1}\right)$ sebesar 0,4237 dan harga $r_{\text {tabel }}$ pada jumlah sampel $160(\mathrm{df}-2)$ pada $\alpha=0,05$ adalah 0,148. Jadi harga $r_{x y}$ lebih besar dari $r_{\text {tabel }}$, berarti koefisian korelasi adalah signifikan. Artinya pengaruh kearifan lokal terhadap perilaku peserta didik di SMA Negeri 1 Kabila terbukti. Hal ini sesuai dengan pendapat Nuraini Asriati yang menyatakan bahwa kearifan lokal menanamkan tanggung jawab, disiplin, mandiri, jujur, kasih saying, peduli, hormat dan santun. Sehingga dipahami perilaku yang baik dari peserta didik di SMA Negeri 1 Kabila dapat dipengaruhi oleh kearifan lokal.

Analisa di atas, berdasarkan hasil penghitungan koefisien determinasi kearifan lokal terhadap perilaku peserta didik didapat sebesar 17,95\%, selebihnya $82,05 \%$ dipengaruhi faktor-faktor lain. Maknanya, terdapat banyak faktor yang memengaruhi perilaku peserta 
didik di SMA Negeri 1 Kabila. Faktor-faktor tersebut dapat berasal dari kemampuan guru, iklim sekolah dan dukungan keluarga baik secara moril maupun materil.

\section{Kecerdasan spiritual berpengaruh secara signifikan terhadap perilaku peserta didik}

Berdasarkan hasil analisis yang mengukur tingkat kecerdasan spiritual dengan perilaku peserta didik di SMA Negeri 1 Kabilakecerdasan spiritual peserta didik berada pada kategori baik dengan prosentase 76,88 \%. Dari 160 peserta didik yang dijadikan sampel seluruhnya memiliki tingkat kecerdasan spiritual dengan rerata 89. Hal ini membuktikan bahwa aspek-aspek spiritualitas yang meliputi kemampuan seseorang untuk bersikap fleksibel, memiliki tingkat kesadaran yang tinggi, kemampuan untuk menghadapi dan memanfaatkan penderitaan, kualitas hidup yang diilhami oleh visi dan nilai-nilai, kemampuan untuk melihat keterkaitan berbagai hal, kecenderungan untuk bertanya "Mengapa?" atau "Bagaimana jika?" dalam rangka mencari jawaban yang benar memberikan dampak positif bagi perilaku positif peserta didik. Adapun kegiatan-kegiatan spiritual keagamaan yang dikembangkan di sekolah seperti kegiatan senada (seni nada dan dakwah), sholat Dzuhur berjamaah, membaca al-qur'an sebelum pelajaran dimulai, membiasakan berdo'a sebelum dan sesudah pelajaran dimulai dan lain sebagainya. Kegiatan-kegiatan tersebut di atas mampu merangsang hati dan pikiran peserta didik untuk selalu berperilaku positif, tegar dalam menghadapi masalah dan bekerja keras untuk meraih kesuksesan karena hati dan pikirannya selalu berusaha dan berdo'a memohon petunjuk kepada Tuhan untuk selalu diberi jalan yang baik. Dengan demikian, peningkatan kecerdasan melalui kegiatan beribadah dapat dijadikan sebagai alat untuk menanggulangi perilaku buruk seseorang. Hal itu sesuai dengan firman Allah Swt di dalam al-quran surat Al-Ankabut ayat 45:

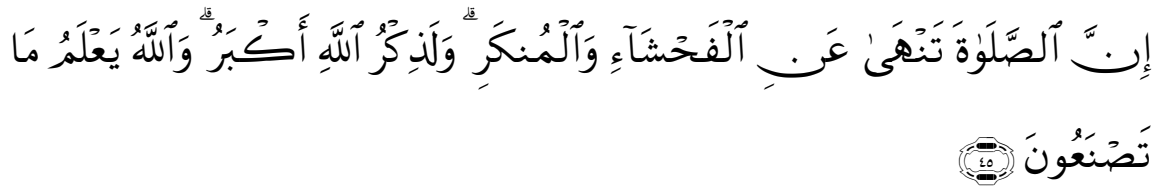

Terjemahnya:"Sesungguhnya shalat itu mencegah dari (perbuatanperbuatan) keji dan mungkar, selagi ia benar-benar mengerjakannya. (Dan segungguhnya mengingat Allah adalah lebih besar keutamaannya) daripada ibadah-ibadah dan amalamal ketaatan lainnya. (Dan Allah mengetahui apa yang telah kalian lakukan) maka Dia membalasnya kepada kalian. " (QS. Al-Ankabut: 45) 
Ayat di atas menjelaskan bahwa perbuatan-perbuatan keji dan mungkar dapat dicegah dengan rajin menjalankan ibadah shalat dan mengingat Allah. Sehingga dapat dipahami bahwa bagi peserta didik untuk menghindari perbuatan-perbuatan yang negativ dapat ditanggulangi dengan memperbanyak ibadah shalat dan berzikir selagi ia benar-benar mengerjakannya.

Secara singkat kecerdasan spiritul adalah kecerdasan untuk menghadapi dan memecahkan persoalan makna dan nilai, yaitu kecerdasan untuk menilai bahwa tindakan atau jalan hidup seseorang lebih bermakna dibandingkan dengan yang lain. Dalam perspektif keislaman kecerdasan spiritual atau kecerdasan ruhani adalah potensi yang ada pada setiap diri seorang insan, yang mana dengan potensi itu ia mampu beradaptasi, berinteraksi dan bersosialisasi dengan lingkungannya dan merasakan hikmah dari ketaatan beribadah secara vertikal di hadapan Tuhannya secara langsung.

Danah Zohar dan Ian Marshall menyebutkan kecerdasan spiritual dipercaya sebagai kecerdasan puncak kita. Orang-orang yang memiliki kecerdasan spiritual biasanya memiliki dedikasi kerja yang lebih tulus dan jauh dari kepentingan pribadi (egoisme), apa lagi bertindak zalim kepada orang lain. Motivasi-motivasi yang mendorongnya untuk melakukan sesuatu juga sangat khas, yakni pengetahuan dan kebenaran.

Sebagaimana yang dikemukakan oleh Ary Ginanjar Agustian yang menyatakan bahwa dalam kecerdasan spiritual ada prinsipprinsip membangun mental, diantaranya prinsip bintang yang di dalamnya dikemukakan bahwa dalam diri setiap manusia memiliki sifat keindahan dan ingin selalu mulia yang merupakan hakikat jiwa yang diberikan oleh Yang Maha Kuasa, yang menjadi dasar keberhasilan dan bila seseorang telah menyadari sifat-sifatnya jika terus dipupuk menghasilkan kekuatan serta motivasi yang maha dasyat. Dalam kecerdasan spiritual juga memuat prinsip pembelajaran, yang mengarahkan manusia untuk senantiasa menggali dan mengembangkan ilmu pengetahuan serta memiliki pedoman kuat dalam belajar, yaitu berpegang kepada Alquran. Kecerdasan spiritual menjadikan seseorang yang benar-benar utuh secara intelektual, emosional dan spiritual.

Tinggi rendahnya tingkat spiritualitas dapat dianggap penting, hal ini merujuk pada beberapa penelitian sebagaimana dikutip oleh Triantoro Safaria yaitu: Khisbiyah yang menemukan bahwa tingkat religiusitas yang tinggi memiliki dampak positif terhadap peningkatan makna hidup, Urbayatun menemukan bahwa mahasiswa 
yang memiliki tingkat religiusitas tinggi memiliki dampak positif lebih besar ketimbang dampak negatif dalam kehidupan sehariharinya, sedangkan Subandi menemukan bahwa remaja yang tingkat religiusitasnya baik, ternyata jarang merasa cemas dalam hidup sehariharinya.

Pada penelitian ini Kecerdasan spiritual peserta didik yang diterima tergolong baik dari sampel yang diambil, hal itu mengindikasikan bahwa peserta didik SMA Negeri 1 Kabila termasuk anak-anak yang peduli terhadap kebutuhan spiritualitasnya. Mereka selalu semangat ketika kegiatan senada (seni nada dan dakwah), diajak sholat berjama'ah, berdzikir bersama dan membaca kitab suci AlQur'an. Kebiasaan-kebiasaan yang baik yang diatanamkan sejak dini akan memberikan dampak yang baik ketika peserta didik sudah lulus dari sekolah tersebut. Tingkat kecerdasan spiritual yang berada pada kategori baik tersebut selain disebabkan oleh faktor keagamaan juga disebabkan oleh faktor-faktor lain, diantaranya faktor emosional, faktor akademik, faktor budaya, dan faktor kehidupan sehari-hari, karena sesungguhnya kecerdasan spiritual ini dianggap sebagai kecerdasan tertinggi manusia yang mampu mensinergikan semua kecerdasan yang ada, baik kecerdasan kognitif, kecerdasan emosional dan kecerdasan spiritual itu sendiri. Faktor emosional disini kemungkinan menjadi salah satu faktor yang menentukan tingkat kecerdasan spiritual siswa. Hubungan yang erat antar teman sekelas, intensitas bertemu yang sering, berdiskusi bersama, shalat bersama dan mengaji bersama juga ikut memberi kontribusi dalam tingkat kecerdasan spiritual peserta didik. Selain itu faktor budaya juga ikut memberi andil dalam tingkat spiritualitas peserta didik. Peserta didik di SMA Negeri 1 Kabila sebagian besar berasal dari keluarga yang agamis, ramah dan saling tolong menolong, sehingga untuk mengembangkan kebiasaan-kebiasaan yang baik di sekolah tidak terlalu sulit untuk dilakukan.

Dari hasil analisis korelasi diperoleh harga korelasi $\left(\mathrm{r}_{\mathrm{yx} 1}\right)$ sebesar 0,7128 dan harga $r_{\text {tabel }}$ pada jumlah sampel $160(\mathrm{df}-2)$ pada $\alpha=0,05$ adalah 0,148 . Jadi harga $r_{\mathrm{yx} 2}$ lebih besar dari $\mathrm{r}_{\text {tabel }}$, berarti koefisian korelasi adalah signifikan. Termasuk dalam pengaruh kuat karena pada tabel koefisien korelasi pada area $=0,60-0,79$. Dengan demikian hasil analisis pengujian hipotesis penelitian menyatakan karena $\rho_{Y 2}>0$ maka tolak $\mathrm{H}_{0}$ artinya terdapat pengaruh kecerdasan spiritual terhadap perilaku peserta didik di SMA Negeri 1 Kabila.

\section{Kearifan lokal dan kecerdasan spiritual secara bersama-sama berpengaruh signifikan terhadap perilaku peserta didik}


Sebagai daerah yang didirikan dengan perjuangan sangat besar, Gorontalo memiliki warisan budaya disiplin. Disiplin berarti patuh dan taat. Masyarakat patuh terhadap aturan yang diberlakukan baik dalam adat istiadat, budaya dan tradisi. Hal ini tercermin dari bagaimana masyarakat menjunjung tinggi falsafah hidup mereka. Kepatuhan dan ketaatan masyarakat Gorontalo terhadap aturan-aturan yang ada menjadi pilar penting kemajuan daerah ini.

Manusia sebagai sebaik-baik makhluk yang diciptakan Allah seharusnya mampu mengembangkan potensi dalam dirinya, melakukan perbaikan dalam hidupnya, mampu melewati tahaptahap perkembangan secara berkelanjutan dan dapat terus mengembangkan potensi dirinya. Seperti diterangkan dalam Al-Quran surat At-tin ayat 4 :

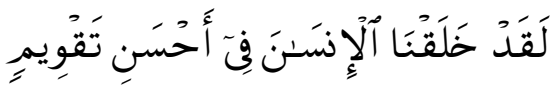

Terjemahnya; Sesungguhnya kami Telah menciptakan manusia dalam bentuk yang sebaik-baiknya.(QS. At-Tin: 4).

Generasi muda atau peserta didik dapat mengembangkan potensinya melalui pendidikan di sekolah. Di dalam lingkungan sekolah terdapat peserta didik wajib mengindahkan tata tertib aturan sekolah. Aturan yang dibuat adalah untuk membentuk mental yang baik bagi seluruh peserta didik. SMA Negeri 1 Kabila sebagai salah satu sekolah rujukan di provinsi Gorontalo dalam upaya mengembangkan potensi peserta didiknya yang berkarakter adalah melalui kegiatan-kegiatan yang mengandung unsur ibadah dan pendidikan berbasis budaya yang menjadi kearifan lokal.

Nilai-nilai kearifan lokal ditanamkan kepada peserta didik di lingkungan sekolah. Lingkungan sekolah adalah lingkungan dimana seluruh nlai-nilai kehidupan diajarkan. Terlebih lagi untuk membentuk karakter peserta didik. Nilai-nilai kearifan lokal tersebut dapat menjadi niali yang diperlukan dalam membangun pendidikan yang berkarakter.

Kecerdasan spiritual merupakan salah satu faktor yang mempengaruhi perilaku peserta didik disamping faktor-faktor yang lainnya seperti kecerdesan intelektual, emosional, lingkungan, budaya dan kemampuan pribadi siswa. Manusia mempunyai kecerdasan spiritual untuk mencapai perkembangan diri yang lebih utuh karena kita memiliki potensi itu. Masing-masing individu membentuk suatu karakter melalui gabungan antara pengalaman dan visi, ketegangan antara apa yang benarbenar kita lakukan dan hal-hal yang lebih besar dan lebih baik yang mungkin kita lakukan. Pada tingkat ego murni kita adalah egois dan ambisius terhadap materi. Akan tetapi kita memiliki gambaran-gambaran transpersonal terhadap kebaikan, keindahan, kesempurnaan, kedermawanan, pengorbanan dan lain-lain. Ia membantu kita menjalani hidup pada tingkatan yang lebih luas. Manusia adalah makhluk hidup yang tidak dapat hidup dengan hanya bergantung kepada kekuatannya 
sendiri. Oleh karena itu manusia disebut sebagai makhluk sosial. Artinya unsur kebersamaan harus ada dan tertanam pada setiap individu. Dalam upaya pembentukan diri yang berkualitas, terdapat landasan diri yang harus mencapai esensi ketahanan pribadi atau karakter yang kuat, yaitu kecerdasan spiritual. Indikasi dari kecerdasan tersebut adalah rasa percaya diri dalam memegang prinsip hidup yang diiringi dengan kemandirian yang kuat dan memiliki visi untuk mengedepankan kepentingan umum dari pada kepentingan pribadi. Berdasarkan analisis data mengenai pengaruh kearifan lokal dan kecerdasan spiritual secara bersama-sama terhadap perilaku peserta didik di SMA Negeri 1 Kabila diketahui bahwa peserta didik memiliki tingkat perilaku yang baik dengan prosentase $86,64 \%$.

Dari analisis korelasi menggunakan korelasi product moment pearson didapatkan hasil sebesar $r_{x y}=0,6188$ dan harga $r_{\text {tabel }}$ pada jumlah sampel $160(\mathrm{df}-2)$ pada $\alpha=0,05$ adalah 0,148 , artinya terdapat pengaruh kearifan lokal dan kecerdasan spiritual secara bersama-sama terhadap perilaku peserta didik di SMA N 1 Kabila.

Jadi harga $r_{x y}$ lebih besar dari $r_{\text {tabel}}$, berarti koefisian korelasi adalah signifikan. Artinya terdapat pengaruh kecerdasan spiritual terhadap perilaku peserta didik di SMA Negeri 1 Kabila terbukti. Berdasarkan uji hipotesis disimpulkan (Ho) ditolak. Kearifan lokal dan kecerdasan spiritual mempunyai pengaruh terhadap perilaku baik bagi peserta didik di sekolah. Tentunya menjadi perhatian bagi tenaga kependidikan untuk senantiasa memberi kegiatan yang dapat meningkatkan nilai kearifan lokal dan kecerdasan spiritual peserta didik dalam menanggulangi perilaku buruk. Kegiatan peningkatan kecerdasan spiritual dapat dilakukan dengan membiasakan kegiatan dakwah, membaca Alquran dan salat berjamaah.

Kearifan lokal merupakan budaya daerah yang harus tetap dilestarikan oleh peserta didik agar dapat peka terhadap lingkungannya. Nilai-nilai kearifan lokal memudahkan peserta didik memahami keadaan lingkungan sekolah baik teman maupun guru. Dengan kemampuan tersebut peserta didik dapat menjalin hubungan harmonis dengan orang lain. Sikap persahabatan dapat ditunjukkan saat belajar kelompok maupun diskusi di kelas. Sehingga dengan kerjasama, tolong menolong pemecahan masalah peserta didik mudah ditemukan solusinya.

Kecerdasan spiritual adalah kemampuan motivasi diri untuk melakukan sesuatu yang khas, yakni pengetahuan dan kebenaran. Dalam perspektif Islam ilmu bermanfaat di dunia dan akhirat jika diperoleh dengan jalan yang benar. Maknanya untuk memperoleh hasil yang baik maka harus dengan cara yang baik pula. Kecerdasan spiritual peserta didik dalam usaha mengontrol perilakunya dalam 
menuntut ilmu menuntunnya dengan cara yang diridai Tuhan dan perintah guru yang benar.

Dengan demikian, kearifan lokal dan kecerdasan spiritual mempunyai andil dalam menentukan keberhasilan peserta didik dalam memperbaiki perilaku yang dapat melanggar aturan-aturan sekolah maupun di masyarakat. Tentunya sudah menjadi keharusan bagi tenaga kependidikan untuk senantiasa memberikan kegiatan yang dapat meningkatkan nilai-nilai luhur melalui pendidikan yang bermuatan kearifan lokal dan kecerdasan spiritual bagi peserta didik agar tidak terjerumus ke perilaku yang buruk.

\section{Kesimpulan}

Peserta didik yang memiliki semangat melestarikan kearifan lokal dalam bentuk kegiatan walimah, membuat tolangga maka perilaku peserta didik untuk taat dan patuh terhadap tata aturan disekolah maupun di masyarakat meningkat. Perilaku positif tersebut diantaranya kasing sayang, santun, tolong menolong, kerja sama, disiplin, menjaga kebersihan lingkungan dan berdoa. (1) Terdapat terdapat pengaruh kecerdasan spiritual terhadap perilaku peserta didik, melalui kegiatan sholat berjamaah, dakwah, mengikuti rohani Islam dapat meningkatkan tingkat kecerdasan spiritual peserta didik. Semakin tinggi tingkat kecerdasan spiritual peserta didik maka peserta didik semakin mampu mengendalikan dirinya untuk tidak berbuat sesuatu yang dapat merugikan dirinya maupun orang lain. Indikator peserta didik yang memiliki tingkat kecerdasan yang tinggi adalah memiliki tingkat kontrol diri, ketabahan, tujuan hidup dan pandai bergaul dengan baik. (2) Terdapat pengaruh kearifan lokal dan kecerdasan spiritual secara bersama-sama terhadap perilaku peserta didik, sehingga peserta didik terbiasa taat dan patuh terhadap aturan sekolah. Bila didukung dengan tingkat kecerdasan spiritual yang tinggi, maka hal ini dapat dijadikan kemampuan mengontrol diri bagi peserta didik untuk tidak melakukan tindakan yang melanggar aturan sekolah dan dapat merugikan peserta didik itu sendiri dan orang lain. 


\section{Daftar Pustaka}

Abdullah, Anastasia Hastuti, dkk, Menjaga Nilai Tradisi Tolangga di Gorontalo Antologi Esai Remaja Gorontalo 2015, (Gorontalo: Kantor Bahasa Provinsi Gorontalo, 2015).

Agustian, Ary Ginanjar, Rahasia Sukses Membangun Kecerdasan Emosi dan Spiritual Berdasarkan 6 Rukun Iman Dan 5 Rukun Islam, Jakarta: Arga, 2001, Cet., ke-10.

- Rahasia Sukses Membangun Kecerdasan Emosi dan Spiritual ESQ Emotianal Spiritual Quotient The ESQ Way 165 1 Ihsan, 6 Rukun Iman Dan 5 Rukun Islam, Jakarta: Arga, 2005.

Ahmad, Haidlor Ali, Kearifan Lokal sebagai Landasan Pembangunan Bangsa, Harmoni Jurnal Multikultural \& Multireligius. 34 (IX), 2010.

Ansyor, Mohammad, Kurikulum Hakikat, Fondasi, Desain, dan Pengembangan, Jakarta: Kencana Media, 2015.

Asriati, Nuraini, Mengembangkan Karakter Peserta Didik Berbasis Kearifan Lokal Melalui Pembelajaran di Sekolah, Jurnal Pendidikan Sosiologi dan Humaniora, 2010.

Baharuddin dan Esa Nur Wahyuni, Teori Belajar dan Pembelajaran, Yogyakarta: Ar-Ruzz Media, 2010, Cet., ke-5.

Budiningsih, Asri, Belajar dan Pembelajaran, Jakarta : Rineka Cipta, 2005.

Calvin, Hall S. \& Lindzey, Psikology kebribadian 3, Teori-Teori sifat dan behavioristik, diterjemahkan dari buku Theories of personality, New york, Santa barbara Toronto, 1978, Yogyakarta: Kanisius 1993.

Digdoyo, Eko, Ilmu Sosial dan Budaya Dasar, .Bogor: Ghalia Indonesia, 2015.

Hasan, Aliah B. Purwakania, Psikologi Perkembangan Islam Menyingkap Rentang Kehidupan Manusia dari Prakelahiran hingga Pascakematian, Jakarta: Raja Grafindo Persada, 2006. 
Herimanto dan Winarno, Ilmu Sosial dan Budaya Dasar. Jakarta: PT Bumi Aksara, 2010.

Iskandar, Metodologi Penelitian Pendidikan Dan Sosial (Kuantitatif Dan Kualitatif), Jakarta: Gaung Persada Press, 2009, Cet., ke2.

J.P. Chaplin, Kamus Lengkap Psikologi, terj. Kartono Kartini, Judul asli, "Dictionary of Psychology", Jakarta : Rajawali Pers, 1999.

Kadir, Statistika untuk Penelitian Ilmu-ilmu Sosial (Dilengkapi dengan Output Program SPSS), Jakarta: Rosemata Sampurna, 2010 .

M.Arifin, Pedoman Pelaksanaan Bimbingan dan Penyuluhan Agama, Jakarta: PT.Golden Trayon Press, 1994, Cet., ke-5.

Mujib, Abdul dan Jusuf Mudzakir, Nuansa-Nuansa Psikologi Islam, Jakarta: Rajawali Pers, 2002.

Pidarta, Made, Landasan Kependidikan. Jakarta: PT Rineka Cipta, 2007.

Prasetyo, Zuhdan K., Pembelajaran Sains Berbasis Kearifan Lokal. Prosiding, Seminar Nasional Fisika dan Pendidikan Fisika. Surakarta: FKIP UNS, 2013.

Rahmat, Jalaludin, SQ for Kids: mengembangkan Kecerdasan Spiritual Anak sejak Usia Dini, Bandung: Mizan, 2007.

Ramayulis, Ilmu pendidikan Islam, Jakarta: Kalam Mulia, 2010, Cet., ke-9.

Ridwan, Nurma Ali, Landasan Keilmuan Kearifan Lokal. Jurnal Studi Islam dan Budaya. 1(V). 2007.

Sarwono, Sarlito W, Psikologi Remaja, Jakarta: Rajawali Pres, 2011, Cet., ke-14.

Setiyadi, Putut, Pemahaman Kembali Local Wisdom Etnik Jawa dalam Tembang Macapat dan Pemanfaatannya sebagai Media Pendidikan Budi Pekerti Bangsa, Magistra, 2012.

Slameto, Belajar dan Faktor-faktor yang Mempengaruhinya, (Jakarta: PT Rineka Cipta, 2004), Cet., ke-4, hlm. 57.

Sugiyono, dan Hariyanto, Belajar dan Pembelajaran: Teori dan Konsep Dasar, Bandung: Remaja Rosdakarya, 2011.

Winarno, Surakhmad, Pengantar Penelitian Ilmiah, .Bandung: Tarsito, 2004. 
Yatim, Riyanto, Paradigma Baru Pembelajaran, .Jakarta : Pranada Media Group, 2009.

Zohar, Danah dan Ian Marshall, $S Q$ Kecerdasan Spiritual di Terjemahkan dari SQ: Spiritual Intellegence-The Ultimate Intellegence oleh Rahmani Astuti, Ahmad Nadjib Burhani, dan Ahmad Baiquni, Bandung: PT Mizan Pustaka, 2007, Cet., ke10 . 